\title{
IMPACTS OF DIEBACK AT PINE LAKE, TASMANIA
}

\author{
by Jennie Whinam, Nicki Chilcott and Tim Rudman
}

(with six tables, five text-figures and one appendix)

Whinam, J., Chilcott, N. \& Rudman, T., 2000 (31:xii): Impacts of dieback at Pine Lake, Tasmania. Pap. Proc. R. Soc. Tasm. 135: 4149. https://doi.org/10.26749/xstpp.135.41 ISSN 0080-4703. Nature Conservation Branch, Resource Management and Conservation, Department of Primary Industries, Water and Environment, PO Box 44a, Hobart, Tasmania, Australia 7001.

The possibility of a new plant disease in alpine plant communities was identified in 1994, following an investigation of dead and dying plants in the Central Plateau Conservation Area. Seven areas of dieback were identified within the affected catchment and monitored. Symptoms included leaf discolouration, loss of foliage and plant death. No disease of this type has previously been recorded in the Australian alpine environment. Temporal and spatial patterns in disease development along with evidence of lesions on plant roots suggested a soil and water-borne pathogen could be contributing to the dieback. A species of Phytophthora was isolated from plant material collected at the site.

Investigations have focussed on whether plants at the limits of their range have been more susceptible to a combination of below-average rainfall, above-average temperatures and the presence of pathogens. Initial rapid development of disease symptoms suggested the potential for local extinction of species, including Tasmanian endemics such as Athrotaxis cupressoides, and significant alteration to community structure through a loss or substantial reduction in the tree and shrub layers. However, longer term monitoring suggests short-term disease events followed by recovery of surviving plants with only localised impacts. Management actions have been concentrated on containment, monitoring impacts and investigation of the cause of the dieback.

Key Words: Pine Lake dieback, Tasmania, ecology, alpine, disease monitoring, Phytophthora.

\section{BACKGROUND}

Symptoms of recent dieback were observed at a number of sites in the vicinity of Pine Lake and Mickeys Creek in the Tasmanian Central Highlands (fig. 1). The dieback appears to have first occurred in the vicinity of the Pine Lake Boardwalk, below the outfall of a road culvert. In November 1990, two recently dead pencil pines, Athrotaxus cupressoides, were observed at Pine Lake. Other pines at the site appeared healthy with new seasonal growth. Soil samples were taken for pathogen screening; however, no indication of the cause of death was forthcoming. In May 1994, it was observed that there had been an increase both in the area affected by dieback and the number of dead plants at Pine Lake below an area of roadworks (Whinam 1994). A range of plant species was affected in a small area, and a temporal sequence of disease development spreading from the centre of the patch outwards was evident. This suggested the possibility of a new and potentially serious disease in subalpine conifer and heath communities. A second patch of dead pines was also observed on the northern shore of Pine Lake, in an area undisturbed by roadworks. A list of dead and dying plants was compiled, and soil and plant samples were collected for analysis. Parks and Wildlife Service staff and recreational users were requested to report any areas of dieback observed for follow-up investigation.

In 1994, a microscopic root rot fungus was found in association with dieback from a diseased Richea scoparia at Pine Lake (Wardlaw 1995). This fungus was thought to be an undescribed species of Phytophthora known from North America, which had been associated with plant disease in fir and some fruit and berry crops. Another fungus, identified as Pythium sp., was also isolated from the site. In response to a potentially new disease incursion to Tasmania, with possible effects on the subalpine plants at Pine Lake and the fruit and berry industries in Tasmania, a quarantine area at Pine Lake and a research program to investigate the Phytophthora were initiated.

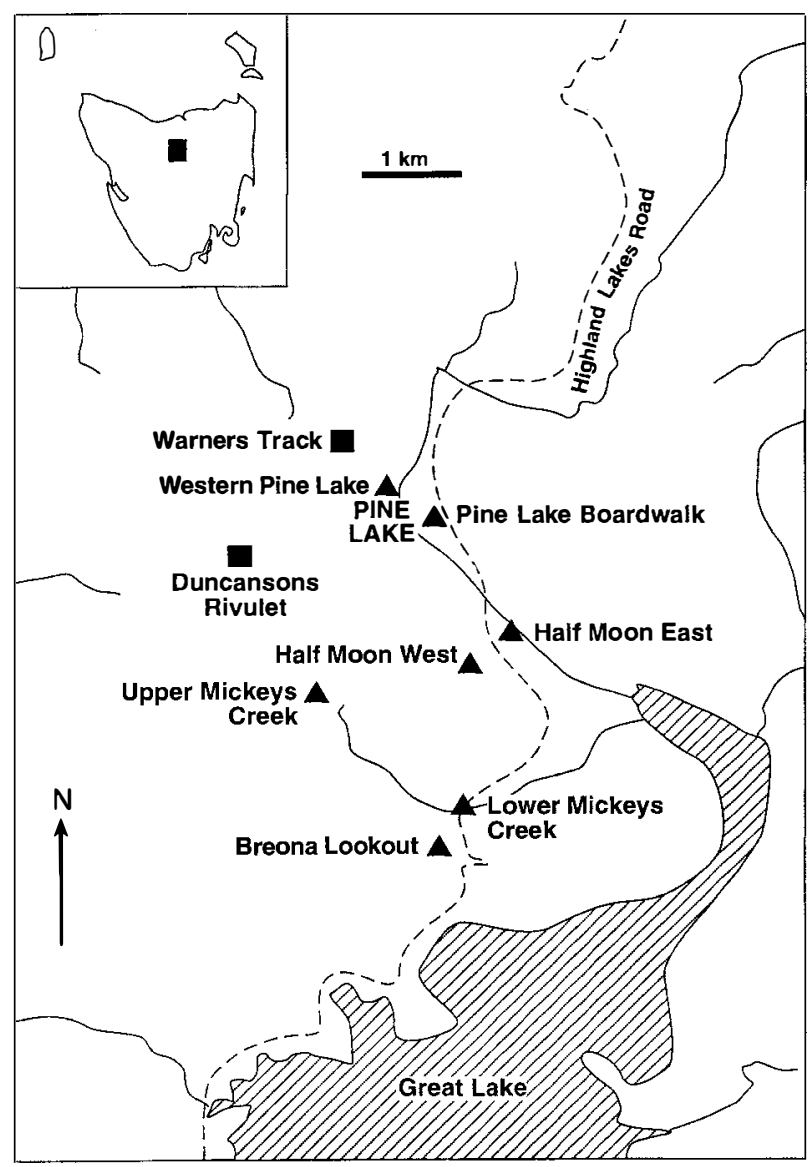

FIG. 1 - Dieback monitoring sites (triangles) near Pine Lake, Central Plateau, Tasmania and the two control sites (squares). 
The identification of a potential pathogen not previously recorded in Tasmania indicated a potential incursion which required a quarantine response. As this was a new record for Australia and the first record of Phytophthora at high altitude, a response plan was implemented by the Parks and Wildlife Service to ascertain the significance of the find (Rudman \& Whinam 1995). The plan consisted of three components: interim quarantine, monitoring disease impacts, diagnosis of cause.

The identification of potential pathogens and determination of cause were undertaken in partnership with the University of Tasmania (Chilvers 1998, Mohammed \& Shanahan 2000). This paper addresses the monitoring conducted at Pine Lake and describes the process of containment. The role of local climate on change in plant health is investigated.

\section{SITE DESCRIPTIONS}

Pine Lake and the surrounding study areas are located at the northeastern edge of the Central Plateau at an altitude of about $1200 \mathrm{~m}$ (fig. 1). The Central Plateau is a broad, undulating highland area in central Tasmania (Pemberton 1986).

\section{Public Use of the Area}

The observed impacts of Pine Lake dieback indicate that the values for which the World Heritage Area (WHA) was declared are being adversely affected. There is a long history of public use of the Central Plateau for hunting, fishing, walking, skiing and sightseeing activities, which are provided for in the WHA Management Plan.

\section{Geology and Vegetation}

The Pine Lake region covers the area immediately south of the Central Plateau rim and consists of undulating terrain containing large numbers of lakes, as a result of recent glaciations. The area consists of rocky ridges, hills and swamps, and is underlain throughout by Jurassic dolerite with relatively simple yellowish-brown gradational soils. Exposed peats around Pine Lake are subject to serious frost heave problems, having lost the protective insulation of vegetation (Pemberton 1986).

Vegetation communities in the Pine Lake region form a mosaic which appears to vary in response to changes in altitude, climate, topography and soil drainage. Areas covered by peat usually have a dense cover of vegetation dominated by Richea spp. and bolster plants, with dense Astelia alpina beds around creeks. Interspersed with this vegetation are Empodisma minus, Baloskion australe and Lepidosperma filiforme. Sphagnum cristatum beds are often found in poorly drained hollows and sometimes form raised bogs, while scattered stands of the endemic pine Athrotaxis cupressoides inhabit fire-protected sites. The study area contains significant numbers of mature (up to 800 years) and young $A$. cupressoides (Whinam 1994). Heathland is dominated by Orites spp. (Pemberton 1986). This area has a high number of rare and threatened species and communities, many of which provide important evidence of major evolutionary processes (Kirkpatrick et al. 1993).
Many of these species are local endemics, which are centred on the Central Plateau (Whinam 1994).

\section{Climate}

The climate of the Central Plateau area, including Pine Lake is cool to cold maritime, strongly influenced by prevailing northwest and southwest winds, which are ice-bearing throughout much of the long winter. Cloud frequently descends below $1100 \mathrm{~m}$ and minimum temperatures often fall below $0^{\circ} \mathrm{C}$ in winter. At Liawenee (the closest weather station to the Pine Lake area), the maximum monthly temperatures in summer are below $18^{\circ} \mathrm{C}$ (Corbett 1996). The annual average temperature on the Central Plateau varies between $4^{\circ}$ and $7^{\circ} \mathrm{C}$. Frosts can occur during any month, with July having the highest frequency. Annual rainfall at Liawenee, where it falls on about 200 days of the year, is about $1000 \mathrm{~mm}$ per year (Marsden-Smedley 1994). Annual average rainfall at Pine Lake is $1800 \mathrm{~mm}$ (Whinam 1994). Rain, snow, hail, fog, mist and rime contribute to precipitation in the study area (Whinam 1994).

\section{METHODS}

\section{Climate Analysis - Warm-and-Dry Index}

The index, developed by the Bureau of Meteorology (BarnesKeoghan, unpubl. data), is meant as a simple method of detecting months that were particularly warm and especially dry. It is a number, from -100 (representing cool and wet) to $+\mathbf{1 0 0}$ (warm and dry). Available data were obtained from weather stations at opposite ends of the Plateau: Liawenee (monthly means of daily maximum temperature and total monthly precipitation) and Meander (total monthly precipitation) for the period 1984 to 1999 . Each monthly rainfall total was then ranked against the same month in other years, producing a number from 0 (the driest year) to 100 (the wettest). This is transformed into a Dryness Index which runs from -100 (in the wettest year) to +100 (in the driest). The temperatures were treated in the same way to yield a Warmness Index between -100 (in the coolest year) and +100 (in the warmest). These two indices are then averaged to produce the Warm-and-Dry Index, which could run from -100 (if the coolest year were also the wettest) to +100 (if the warmest year were also the driest). Results of this index along with mean monthly temperature and rainfall data (for Liawenee and Meander areas) were compared with change in species health to investigate the possibility of a correlation between weather conditions and plant health.

\section{Monitoring Plant Health}

Seven dieback sites in the Pine Lake area (fig. 1) were identified for monitoring based on deaths, general discolouration and foliage loss occurring in both $A$. cupressoides and a range of understorey species. Two additional sites (Warners Track and Duncansons Rivulet) with similar floristic and geomorphic characteristics, where plants showed no symptoms of dieback, were chosen as controls. A summary of site descriptions is given in table 1 . A summary of species monitored at each site, and presence of dieback symptoms, is included in the appendix. 
TABLE 1

Site descriptions

Site (AMG coordinates)

Pine Lake Boardwalk (475500 5378600)

Western Pine Lake (475000 5378900)

Upper Mickeys Creek (474300 5376800)

Lower Mickeys Creek (475800 5375600)

Half Moon East (476200 5377400)

Half Moon West (475800 5377100)

Breona Lookout (475500 5375200)

Warners Track (Control) (474500 5379400)

Duncansons Rivulet (Control) (473500 5378200)
Description

Blockstream. Adjacent to Pine Lake. Overstorey Athrotaxis cupressoides. Understorey alpine shrubland.

Blockstream. Adjacent to Pine Lake. Overstorey A. cupressoides. Understorey alpine shrubland.

Upper limit of catchment. Thin peat overlay over blockstream. Overstorey alpine shrubland. Understorey sedges.

Blockstream. Streamside. Overstorey $A$. cupressoides. Understorey alpine shrubland.

Peat overlay over blockstream. Fringing $A$. cupressoides. Understorey alpine shrubland.

Blockstream. Fringing A. cupressoides and Phyllocladus asplenifolius. Understorey alpine shrubland.

Peat layer overlying blockstream. Alpine shrubland with understorey of sedges and grasses.

Top of catchment, located on saddle. Overstorey alpine shrubland. Understorey is low shrubs and rocky.

Peat overlying blockstream. Streamside. Overstorey is fringing $A$. cupressoides and understorey of alpine shrubland.
TABLE 2

Ranking system for recording plant health

\begin{tabular}{ll}
\hline Score & \multicolumn{1}{c}{ Description } \\
0 & No signs of plant stress \\
1 & Some discolouration of plant tips \\
2 & General discolouration and "thinning" of foliage \\
3 & Major loss of foliage cover \\
4 & Dead \\
\hline
\end{tabular}

A total of 530 plants from 15 species were individually tagged. Plastic numbered tags were used to withstand harsh weather conditions. Mapping of tagged plants revealed there was geographical clumping of some plant species. Plant health assessments were made independently by teams of two people using a ranking system that incorporated foliage discolouration and foliage loss, ranging from very healthy $(0)$ to dead (4) (table 2). Each plant was also scored with a $(+)$ or $(-)$ to indicate presence or absence of new growth. Individual plants with health scores of 1 or 2 were preferentially selected for tagging in order to monitor health changes in both negative and positive directions.

Initial assessments were conducted in December 1994. Monitoring at all sites commenced in April 1995 and was completed in April 1999. Sites were monitored twice each year, in March/April (after active growing period) and October (after winter dormant period).

Results obtained from aggregated species data were examined to assess possible trends in temporal change. Changes in species health scores were also tested against rainfall and temperature data and the "warm-and-dry" index, in order to examine any relationship between trends in weather conditions and the onset and progression of disease symptoms.

\section{RESULTS}

\section{Observation of Dieback Symptoms}

Only symptoms of dieback were monitored, as a causal relationship for the dieback had not been established and investigation of the cause was the subject of a separate study (Chilvers 1998, Mohammed \& Shanahan 2000). At Pine Lake, dieback symptoms were observed across a range of plant species. Symptoms were typically chlorosis and anthocyanescence (yellowing and reddening of the leaves respectively) and crown dieback, commonly leading to death in plants belonging to the Proteaceae, Rutaceae, Winteraceae, Cupressaceae and Epacridaceae. Dieback was locally epidemic, demonstrating a distinct temporal sequence of dieback symptoms in the direction of water movement (along drainage lines).

Fifteen species appeared stressed (evidenced by chlorosis and/or crown dieback) or dying. Of these $A$. cupressoides, Richea scoparia, Boronia citriodora, Orites acicularis, $O$. revoluta and Tasmannia lanceolata were most affected.

While all reports of dieback from alpine areas outside the Quarantine Area were investigated, no other site displayed dieback symptoms similar to the Pine Lake area. Patches of dieback in pencil pines and conifer shrub communities were recorded in several mountain areas of central and southwestern Tasmania; however, some of these additional dieback sites have been associated with a stem canker (Yuan et al. 2000). Dieback has also been recorded as occurring at a number of locations in the Halfmoon and Mickeys Creek catchments.

\section{Climate Analysis}

There were no major climatic trends that could be correlated with the incidence of dieback at Pine Lake. Both temperature and rainfall fluctuate from one extreme to another from year 
to year, with no apparent pattern between months or years and no correlation between drought and the onset of disease (fig. 2). The "warm-and-dry index" developed by the Bureau of Meteorology (fig. 3) shows extremes in temperature and rainfall for individual months. The warm, wet spring and summer of 1998 coincided with a general improvement in health at both control and non-control sites for all species. Figure 4 demonstrates the absence of a strong correlation between weather conditions and changes in health scores of plants at the major sites.

\section{Monitoring Plant Health}

Data collected from all dieback sites (Upper Mickeys Creek, Lower Mickeys Creek, Pine Lake Boardwalk, Western Pine Lake) were combined and frequency histograms were plotted to show distribution of health scores. This analysis showed that between 1994 and April 1999 the number of plants with health scores greater than 0 (therefore not healthy) decreased for some species, indicating an improvement in plant health over the monitoring period (fig. 5a). The results suggest a substantial improvement in the health of $O$. acicularis, $T$. lanceolata, $R$. scoparia and $R$. sprengelioides individuals.

There was a high percentage of unhealthy $A$. cupressoides at the commencement of monitoring at both control and non-control sites. This species appears to have recovered over the four-year monitoring period. Improvement in plant health is substantially greater at control compared with dieback sites (fig. 5b). By 1999, 75\% of scored $A$. cupressoides were in Class 0 , compared with only $25 \%$ in 1995. There was no significant change in the recorded health of other species.

Species data from all sites were combined into two groups (control and dieback sites) to assess changes in health scores over time. Changes in the health of the seven dominant plant species in the area were examined. No discernible pattern appears in health scores, with only minor changes in health scores during the monitoring period. Species data was then collated into sites to examine health trends.

Frequency of health scores (combined species) for each site were calculated and are presented in table 3 . Higher numbers of plants were monitored at Pine Lake Boardwalk (table 4) and Western Pine Lake (table 5) allowing assessment of the dominant species. While many species were tagged, the low numbers of individuals of each species at sites has resulted in us assessing the health of each site by aggregating species scores.

\section{Dieback Sites}

\section{Pine Lake Boardwalk}

Overall species health at this site was monitored through health scores of all species (aggregated). A number of plants improved in health while an equal number of individuals died over this period (table 4).

Initial surveys in December 1994 recorded a total of 23 (out of 28 tagged trees) A. cupressoides (pencil pine) showing symptoms of dieback. By 1995, all individuals showed symptoms of dieback. Recent monitoring indicates that there has been little recovery in the pencil pines, with 28 individuals recorded as showing symptoms in 1999. Monitoring of $A$. cupressoides shows that the majority of individuals are in class 2 (general discolouration and thinning).

There was some decline in the health of $R$ scoparia by 1999, no recovery and no deaths. The analysis of health scores for $T$. lanceolata shows that there was an increase in healthy plants. $O$. acicularis showed an increase in the number of both healthy and dead plants over time (table 4).

\section{Western Pine Lake}

Distribution of combined species health scores of the four dominant species (A. cupressoides, $R$. scoparia, T. lanceolata and $O$. acicularis) for this site showed a general improvement in plant health (table 3 ).

Monitoring of $A$. cupressoides showed a general improvement in health over time. Only small numbers of individuals of other species ( $R$. sprengelioides, Bellendena montana and Boronia citriodora) were present at this site, but the general trend is for an improvement in health (table 5).

\section{Upper Mickeys Creek}

While only a small number of individuals of each species are tagged at this site, there has been a general improvement in health over time in the 63 tagged individuals (table 3 ).

\section{Lower Mickeys Creek}

A summary of health scores for this site showed that, while there was an increase in the number of healthy plants over time, there was also a substantial increase in the number of dead plants (table 3).

\section{Half Moon East}

Summaries of health scores showed that $A$. cupressoides again was the most susceptible species, with nine out of ten tagged individuals showing symptoms of dieback by 1999 . For other species at this site the general trend was an increase in healthy plants with only one death (table 3 ).

\section{Half Moon West}

The trend for all species at this site was a general improvement in health over time, with no mortality (table 3).

\section{Breona Lookout}

The trend for all species at this site was a general improvement in health over time, with two mortalities (table 3).

\section{Control Sites}

\section{Warners Track}

There has been an increase in the number of healthy plants over time at this site, with two mortalities (table 3).

\section{Duncansons Rivulet}

There was a marked increase in mortality at this site over time (table 3), due to the impacts of native animal browsing (table 6). 


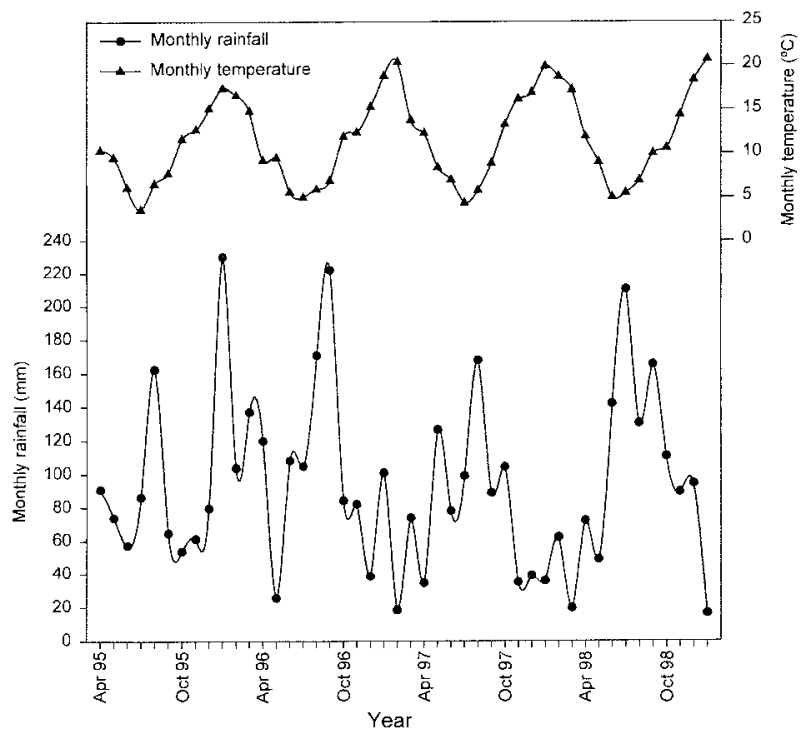

FIG. 2 - Mean monthly temperature and rainfall for the Liawenee weather station, April 1995 to January 1999. Data from Bureau of Meteorology.

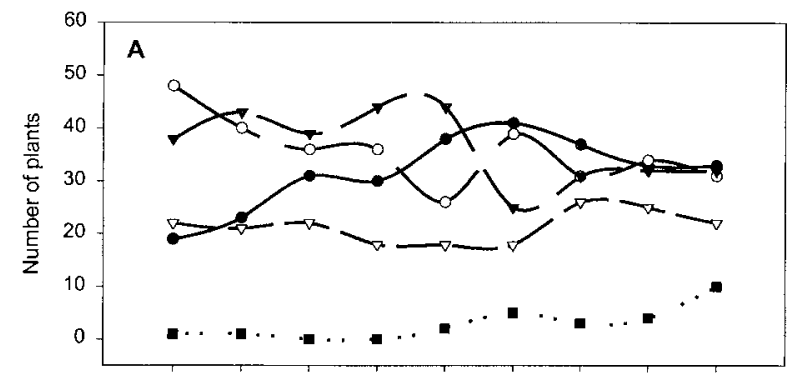

Apr95 Oct95 Apr96 Oct96 Apr97 Oct97 Apr98 Oct98 Apr99
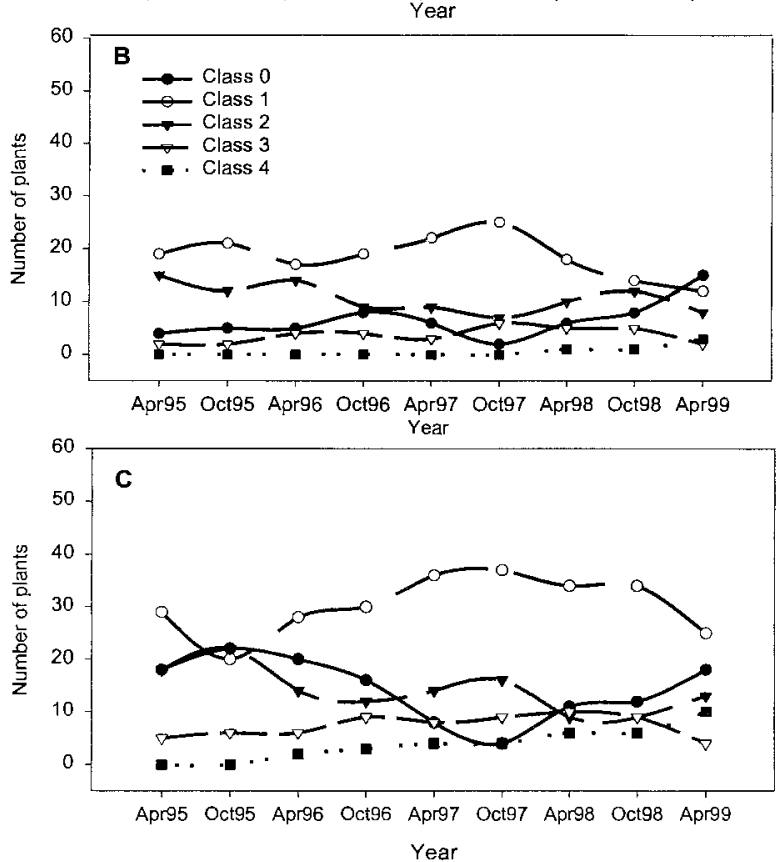

FIG. 4 - Health scores at major monitoring sites (A) Pine Lake, (B) Western Pine Lake and (C) Duncansons Rivulet at each monitoring date. See table 2 for key to health classes.

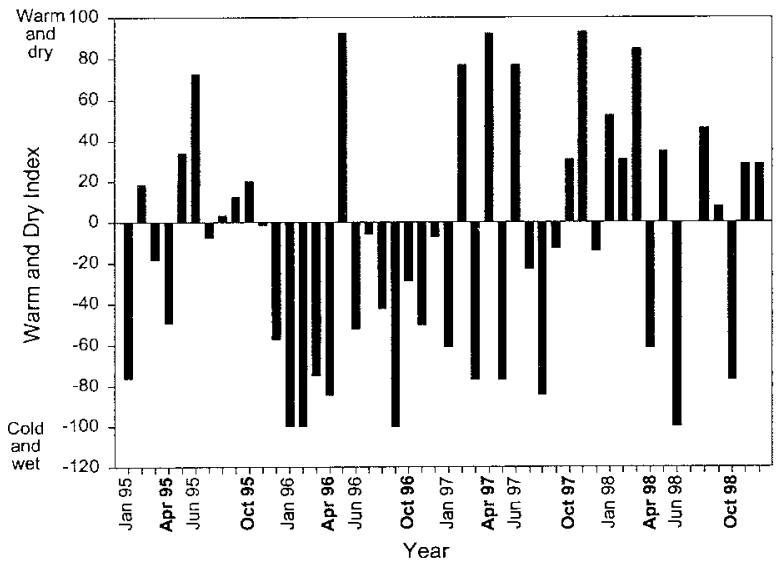

FIG. 3-Warm-and-dry index (calculated by the Bureau of Meteorology, Barnes-Keoghan 1999) for the months during which sites were monitored (indicated by bold type).
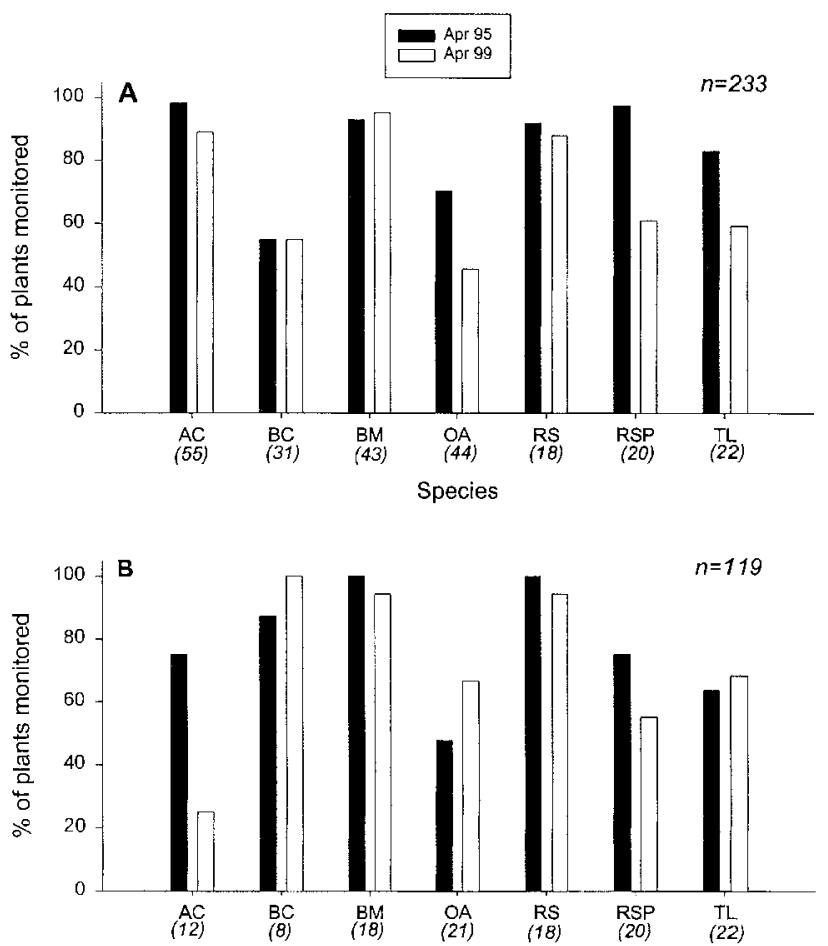

FIG. 5 - Percentage of total plants monitored (A) dieback sites and $(B)$ control sites with health scores not class 0 . Number of individuals in each species group is indicated in brackets on the category axis. Key to species: $A C$, Athrotaxis cupressoides; $B C$, Boronia citriodora; $B M$, Bellendena montana; $O A$, Orites acicularis; $R S$, Richea scoparia; $R S P$, R. sprengelioides; $T L$, Tasmannia lanceolata. 
TABLE 3

Plant health scores at all sites in April 1995 and April 1999

\begin{tabular}{|c|c|c|c|c|c|c|c|}
\hline \multirow[b]{2}{*}{ Site } & \multicolumn{7}{|c|}{ Frequency of health scores* } \\
\hline & Year & 0 & 1 & 2 & 3 & 4 & Total \\
\hline \multirow[t]{3}{*}{ Pine Lake Boardwalk } & 1995 & 19 & 48 & 38 & 22 & 1 & 128 \\
\hline & 1999 & 31 & 30 & 32 & 22 & 13 & 128 \\
\hline & Change & +12 & -18 & -6 & 0 & +12 & \\
\hline \multirow[t]{3}{*}{ Western Pine Lake } & 1995 & 4 & 19 & 15 & 2 & 0 & 40 \\
\hline & 1999 & 15 & 12 & 8 & 2 & 3 & 40 \\
\hline & Change & +11 & -7 & -7 & 0 & +3 & \\
\hline \multirow[t]{3}{*}{ Upper Mickeys Creek } & 1995 & 6 & 25 & 22 & 10 & 0 & 63 \\
\hline & 1999 & 14 & 26 & 11 & 9 & 3 & 63 \\
\hline & Change & +8 & +1 & -11 & -1 & +3 & \\
\hline \multirow[t]{3}{*}{ Lower Mickeys Creek. } & 1995 & 15 & 36 & 27 & 11 & 1 & 90 \\
\hline & 1999 & 27 & 23 & 19 & 10 & 11 & 90 \\
\hline & Change & +12 & -13 & -8 & -1 & +10 & \\
\hline \multirow[t]{3}{*}{ Half Moon East } & 1995 & 25 & 19 & 10 & 4 & 0 & 58 \\
\hline & 1999 & 33 & 10 & 9 & 5 & 1 & 58 \\
\hline & Change & +8 & -9 & -1 & +1 & +1 & \\
\hline \multirow[t]{3}{*}{ Half Moon West } & 1995 & 20 & 12 & 5 & 0 & 0 & 37 \\
\hline & 1999 & 27 & 8 & 2 & 0 & 0 & 37 \\
\hline & Change & +7 & -4 & -3 & 0 & 0 & \\
\hline \multirow[t]{3}{*}{ Breona } & 1995 & 2 & 7 & 7 & 4 & 0 & 20 \\
\hline & 1999 & 6 & 7 & 3 & 2 & 2 & 20 \\
\hline & Change & +4 & $o$ & -4 & -2 & +2 & \\
\hline \multirow[t]{3}{*}{ Warners Track } & 1995 & 11 & 14 & 21 & 5 & 0 & 51 \\
\hline & 1999 & 16 & 21 & 11 & 1 & 2 & 51 \\
\hline & Change & +5 & +7 & -10 & -4 & +2 & \\
\hline \multirow[t]{3}{*}{ Duncansons Rivulet } & 1995 & 18 & 30 & 18 & 5 & 0 & 71 \\
\hline & 1999 & 19 & 25 & 13 & 4 & 10 & 71 \\
\hline & Change & +1 & -5 & -5 & -1 & +10 & \\
\hline
\end{tabular}

* Change in health scores shown as + (increase) or - (decrease) in change column. See table 2 for key to health scores.

TABLE 4

Frequency of health scores for major species at Pine Lake Boardwalk

\begin{tabular}{lllccccc}
\hline & \multicolumn{7}{c}{ Frequency of health scores* } \\
\cline { 2 - 8 } Species & Year & 0 & 1 & 2 & 3 & 4 & Total \\
\hline Athrotaxis cupressoides & 1995 & 0 & 6 & 18 & 4 & 0 & 28 \\
& 1999 & 0 & 8 & 13 & 7 & 0 & 28 \\
& Change & 0 & +2 & -5 & +3 & 0 & \\
Richea scoparia & 1995 & 4 & 12 & 8 & 4 & 0 & 28 \\
& 1999 & 2 & 10 & 13 & 3 & 0 & 28 \\
\multirow{5}{*}{ Tasmannia lanceolata } & Change & -2 & -13 & +5 & -1 & 0 & \\
& 1995 & 5 & 14 & 3 & 7 & 1 & 30 \\
& 1999 & 14 & 3 & 4 & 4 & 5 & 30 \\
Orites acicularis & Change & +9 & -11 & +1 & -3 & +4 & \\
& 1995 & 3 & 7 & 3 & 5 & 0 & 18 \\
& 1999 & 7 & 3 & 0 & 4 & 4 & 18 \\
& Change & +4 & -4 & -3 & -1 & +4 & \\
\hline
\end{tabular}

* See table 2 for key to health scores. 
TABLE 5

Frequency of health scores for major species at Western Pine Lake

\begin{tabular}{|c|c|c|c|c|c|c|c|}
\hline \multirow[b]{2}{*}{ Species } & \multicolumn{7}{|c|}{ Frequency of health scores* } \\
\hline & Year & 0 & 1 & 2 & 3 & 4 & Total \\
\hline \multirow[t]{3}{*}{ Athrotaxis cupressoides } & 1995 & 1 & 4 & 4 & 1 & 0 & 10 \\
\hline & 1999 & 5 & 2 & 2 & 1 & 0 & 10 \\
\hline & Change & +4 & -2 & -2 & 0 & 0 & \\
\hline \multirow[t]{3}{*}{ Richea scoparia } & 1995 & 0 & 3 & 3 & 0 & 0 & 6 \\
\hline & 1999 & 1 & 4 & 1 & 0 & 0 & 6 \\
\hline & Change & +1 & +1 & -2 & 0 & 0 & \\
\hline \multirow[t]{3}{*}{ Tasmannia lanceolata } & 1995 & 1 & 3 & 1 & 0 & 0 & 5 \\
\hline & 1999 & 2 & 1 & 2 & 0 & 0 & 5 \\
\hline & Change & +1 & -2 & +1 & 0 & 0 & \\
\hline \multirow[t]{3}{*}{ Orites acicularis } & 1995 & 0 & 3 & 2 & 0 & 0 & 5 \\
\hline & 1999 & 4 & 1 & 0 & 0 & 0 & 5 \\
\hline & Change & +4 & -2 & -2 & 0 & 0 & \\
\hline
\end{tabular}

* See table 2 for key to health scores.

TABLE 6

Number of plants browsed at each site

\begin{tabular}{lccc}
\hline Site & No. plants browsed & Total no. plants & $\begin{array}{c}\text { Percentage } \\
\text { of total plants }\end{array}$ \\
\hline Duncansons Rivulet & 29 & 72 & 40.3 \\
Western Pine Lake & 9 & 40 & 22.5 \\
Breona & 3 & 20 & 15.0 \\
Lower Mickeys Creek & 7 & 92 & 7.6 \\
Half Moon East & 2 & 59 & 3.4 \\
Upper Mickeys Creek & 2 & 64 & 3.1 \\
Pine Lake Boardwalk & 1 & 133 & 0.8 \\
Half Moon West & 0 & 37 & 0.0 \\
Warners Track & 0 & 51 & 0.0 \\
\hline
\end{tabular}

\section{Browsing Effects}

Monitoring results have been influenced by grazing to varying degrees. Table 6 demonstrates the different grazing effects at each site, with much greater grazing intensity (40\%) occurring at the Duncansons Rivulet control site.

\section{DISCUSSION}

Initially, our greatest concern was the long-term floristic impact on affected alpine communities, particularly the development of dieback in the endemic native conifer, A. cupressoides. A. cupressoides is slow to mature, long-lived, and an infrequent regenerator with a poor seed-dispersal mechanism. Management actions were taken in accordance with the response plan (Rudman \& Whinam 1995), with our aims being quarantine, impact monitoring, investigation of potential causes and subsequent course of action. A project was funded to provide information on the cause and mode of action of dieback in alpine heath and conifer communities, and to verify the identification and pathogenicity of potential pathogens present at diseased sites. An evaluation of the threats posed by Phytophthora "Pine Lake" or other pathogens to native plant flora and economically important plants has been made (Chilvers 1998, Mohammed \& Shanahan 2000).

Action was taken to minimise the potential for spread of putative pathogens isolated from the diseased area until the status of these organisms is known. To help prevent spread of Phytophthora "Pine Lake", the catchments of Halfmoon and Mickeys Creek were declared a Quarantine Area and a Restricted Area under the Quarantine Act 1908, with fences constructed at potential lay-by locations along the highway.

The Department of Infrastructure, Energy and Resources (DIER) extended the sealing of the Lake Highway a further $3 \mathrm{~km}$ through the quarantine area to minimise movement of road gravels. DIER also stabilised batters to reduce silt loading on adjacent vegetation to minimise adverse impacts on dieback areas.

Monitoring of dieback symptoms in the Pine Lake area was complicated by factors operating over a wide area. In the initial (November 1994) spring/summer monitoring period, an unseasonally heavy, late snow cover was observed at the dieback area. Frost burning was seen on plants such 
as T. lanceolata and $N$. cunninghamii in spring, and snow caused stem breakage of $O$. acicularis and $R$. scoparia. Patchy dieback of branch tips on the crowns of $A$. cupressoides was observed to be associated with periods of high temperature and not related to soil moisture levels. Surviving foliage maintained its healthy condition. Browning-off in $B$. citriodora and $O$. acicularis was also observed. These stresses were also evident in other alpine and subalpine communities in central and northern regions of Tasmania and at $\mathrm{Mt}$ Field National Park in the south. These damage symptoms could be distinguished in the field from the broad floristic signature and patterning of dieback occurring at Pine Lake. While these climatic events obviously were regionally significant, pine stands immediately adjacent to the dieback areas did not show the same symptoms and deaths, suggesting other factors were contributing to the dieback. Native animal browsing has also confounded monitoring results.

It is likely that the dieback is the result of a combination of factors. As a result of this, it is only possible for us to monitor a change in plant health at the sites, comparing control to dieback sites without speculation as to a single cause of the dieback. In the case of Pine Lake dieback, the absence of a proven causal agent and the capacity to reliably isolate it made the process of monitoring dieback difficult. The inclusion of sites for monitoring was by necessity subjective, and monitoring the progress of symptom development and distribution of potential pathogens was not possible within this project. Improvement of these techniques will enable ecological monitoring to be in place early in dieback events, enabling a better indication of dieback progression and impact.

Following identification of possible dieback sites, there are still a number of problems encountered. Sample size is restricted by the labour intensity of monitoring and the sheer practicality of tagging large numbers of plants. Comparison of dieback effects on different species is limited by localised occurrence (i.e. species do not occur at all sites) and by species clumping at sites. These factors make it impossible to achieve an equal sample size for each species at all sites. A limited sample size increases the risk that dieback symptoms will not be detected in that species during the monitoring period.

Monitoring results over the past five years indicate that the impact on the pines has been localised, without significant community structural change. Such structural change is a feature recorded at other disease sites (Weste 1994, Wills 1992). There was no significant decline in health of other species at the dieback sites. No obvious trends or correlation with climatic triggers were evident.

Species health assessments at the control site show an increase in mortality at the end of the monitoring period - a feature not evident in the disease sites. This can be associated with our visual observation of increased browsing damage at the control sites during this time.

While extreme variations in temperature and precipitation occurred on both monthly and yearly time-scales during the monitoring period, no patterns in the weather data were discerned, and there was no discernible correlation between these extremes and plant health. Where pathogens are present, dieback may be dependent on a suite of environmental and host plant conditions to cause disease (Wardlaw \& Palzer 1988). Improvement in plant health in the dieback sites indicates the factors that have been interacting are no longer producing an environment conducive to a decline in plant health.

\section{FUTURE MANAGEMENT}

Any new reports of dieback in subalpine communities will continue to be investigated to increase our understanding of the patterns of dieback and help identify causes, enabling early action on any new outbreaks that may be discovered. Lower intensity ecological monitoring will be continued in target areas.

Four years of ecological monitoring and pathology results suggest that the scale and intensity of the dieback may not be as severe as initially anticipated; however, the use of the precautionary principle has enabled effective management of a potentially serious environmental threat. At its worst, this situation could have resulted in local extinctions of species of conservation significance at the limits of their range (e.g. $A$. cupressoides) and an alteration in alpine community structure. It was recognised that quarantine at an early stage was going to be the most strategic management action until management questions could be addressed.

\section{ACKNOWLEDGEMENTS}

We are grateful to Dylan Kendall, Mike Comfort and Anne McEntee for assistance with field measurements and initial data preparation. Tim Wardlaw provided plant pathology advice throughout this project. Ian Barnes-Keoghan provided the weather analysis. Parks and Wildlife Staff assisted with support and maintenance of the Central Plateau Quarantine Area. Caroline Mohammed and Tim Wardlaw provided useful comments on this manuscript.

\section{REFERENCES}

Chilvers, M., 1998: Pine Lake dieback. Unpubl. Hons thesis, Dep. Agric., Univ. Tasm., Hobart.

CORBETT, S., 1996: Vegetation of the Central Plateau, Tasmanian Wilderness World Heritage Area. Wildl. Rep. 95/3. Parks and Wildlife Service, Tasmania.

Kirkpatrick, J.B., Hutchinson, M.N. \& McQuillan, P.B., 1993: Alpine ecosystems. In Smith, S.J. \& Banks, M.R. (Eds): TASMANIAN WILDERNESS - WORLD HERITAGE VALUES. Royal Society of Tasmania.

MARSDEN-SMEdleY, J., 1994: Western Tasmanian Wilderness WHA Fire Management Plan - Walls of Jerusalem National Park and Central Plateau Conservation Area. Draft report, Tasmanian Parks and Wildlife Service.

Mohammed, C. \& Shanahan, K., 2000: Monitoring of dieback symptoms and soil sampling in areas of native vegetation in the Pine Lake area of central Tasmania. Unpubl. rep., Sch. Agric. Sci., Univ. Tasm.

Parks And WiLdufe Service, 1995: PINE LAKE QUARANTINE AREA CENTRAL PLATEAU: WHY HAS THIS AREA BEEN QUARANTINED? Colour information pamphlet produced by Parks and Wildlife Service.

Pemberton, M., 1986: LAND SYSTEMS OF TASMANIA. REGION 5 - CENTRAL PLATEAU. Department of Agriculture, Tasmania.

Rudman, T. \& Whinam, J., 1995: Interim Pine Lake Dieback Management Plan. Unpubl. rep., Parks and Wildlife Service, Hobart. 
Wardaw, T., 1995: Progress report on studies related to Phytophthora "Pine Lake". Unpubl. intern. rep., Forestry Tasmania, Hobart.

WARDl.Aw, T.J. \& PALzer, C., 1988: Regeneration of Eucalyptus species in an eastern Tasmanian coastal forest in the presence of Phytophthora cinnamomi. Aust. J. Bot. 36: 205-215.

Weste, G., 1994: Impact of Phytophthora species on native vegetation of Australia and Papua New Guinea. Australas. Plant Pathol. 23: 190-209.

WhINAM, J., 1994: Lake Highway Pine Lake, Central Plateau (WHA) Botanical Survey. Report to the Department of Transport and Works. Parks and Wildlife Service, Tasmania.
Whinam, J., McEntee, A. \& Rudman, T., 1996: Pine Lake dieback interim monitoring results. Unpubl. rep., Parks and Wildlife Service, Hobart.

WiLls, R.T., 1992: The ecological impact of Phytophthora cinnamomi in the Stirling Range National Park, Western Australia. Aust. J. Ecol. 17: 145-159.

Yuan, Z.Q., Rudman, T. \& Mohammed, C., 2000: Pseudophacidium diselmae sp. nov. isolated from stem cankers on Diselma archeri in Tasmania, Australia. Australas. Plant Pathol. 29: 215-221.

(accepted 25 June 2001)

APPENDIX

Species monitored and dieback symptoms recorded at each site

\begin{tabular}{|c|c|c|c|c|c|c|c|c|c|c|}
\hline & Symptoms & PLB & WPL & HMW & HME & BRE & UPMK & LMK & DRVT & WAR \\
\hline Athrotaxis cupressoides & chlorosis dieback & - & - & - & - & & - & - & - & \\
\hline Richea scoparia & chlorosis dieback & - & - & - & - & & - & - & - & - \\
\hline$R$. sprengelioides & chlorosis & & $\bullet$ & & - & - & - & & - & \\
\hline Boronia citriodora & chlorosis dieback & - & - & - & & & - & - & - & \\
\hline Tasmannia lanceolata & chlorosis dieback & - & • & - & • & • & - & - & - & - \\
\hline Orites acicularis & chlorosis dieback & - & - & - & - & & - & - & - & - \\
\hline O. revoluta & dieback & - & & - & & & & - & & \\
\hline Bellendena montana & chlorosis & - & - & & - & - & - & - & - & - \\
\hline Telopea truncata & chlorosis & - & & & & & & & & \\
\hline Epacris serpyllifolia & chlorosis dieback & & & & & & - & & & \\
\hline Cyathodes glauca & chlorosis dieback & & & & & & & & & \\
\hline Baeckea gunniana & chlorosis & & & - & & & & & - & \\
\hline Phyllocladus aspleniifolius & chlorosis & & & - & & & & & & \\
\hline
\end{tabular}

PLB = Pine Lake Boardwalk; WPL = Western Pine Lake; HMW = Half Moon West; HME = Half Moon East; BRE = Breona Lookout; UPMK = Upper Mickeys Creek; LMK = Lower Mickeys Creek; DRVT = Duncansons Rivulet; WAR = Warners Track. 